\title{
Optical Instrument
}

National Cancer Institute

\section{Source}

National Cancer Institute. Optical Instrument. NCI Thesaurus. Code C19228.

An instrument used to measure an event involving emission, absorption, or refraction of

light. 